\title{
CORRESPONDENCE
}

\section{BAILLIART'S DYNAMOMETER}

To the Editors of THE BRITISH JoURnAL OF OPHTHALMOLOGY.

DEAR SIRS, - May I congratulate Mr. Foster on his valuable description of the continental clinics, but on one point only I disagree. I have used Bailliart's dynamometer for over fifteen years and $I$ find this a reliable and important method in measuring the arterial tension in different branches of the vascular tree. The method is not easy, but once mastered is as precise as measuring of the blood pressure by a sphygmomanometer. I am usually satisfied with an approximate measurement without taking the intraocular pressure as well.

$$
\begin{aligned}
& \text { I am, Sir, } \\
& \text { Your obedient Servant, }
\end{aligned}
$$

\section{1, PHILPOT STREET, E.1.}

N. Pines.

April 16, 1948.

\section{OBITUARY}

\author{
H. SECKER WALKER, F.R.C.S. \\ Ophthalmic Surgeon, The General Infirmary at Leeds. \\ April, 1863 - February, 1948.
}

BORN in 1863, the second son of Dr. Thomas Walker of Wakefield, Secker Walker was educated at the Grammar School of that city, and at University College Hospital, London.

Shortly after his appointment as Hon. Asst. Surgeon to the Eye, Ear, Nose and Throat Department of the General Infirmary at Leeds in 1890, he spent six months in Vienna, and after returning was one of the first Englishmen to perform a mastoidectomy.

From 1912, on the division of Ophthalmic and Aural Departments at the Infirmary, he confined his practice to ophthalmic surgery.

In 1914, H.H. The Jam Sahib of Nawanagar (the immortal Ranji) became his patient, after a serious grouse-shooting accident, and in gratitude for his recovery, in addition to naming a ward after. Secker Walker in Nawanagar Hospital, " Ranji " provided the Leeds Infirmary with a new, ophthalmic theatre, and out-patient department. The design of these incorporated many of Secker Walker's own ideas. 
A keen Territorial from the founding of the force in 1908, he carried on the eye departments of the East Leeds' and Beckett Park Military Hospitals from 1914-1918, being presented to His Late Majesty King George V at each of the Royal visits.

He was instrumental in persuading the authorities during this period to accept large numbers of men who had been rejected for defects that would be considered trifling in soldiers today.

Appointed Consulting Surgeon in 1919, he retired to the south, but kept up his professional activities, as a member of the Committee of the Bath Eye Infirmary, Pensions Secretary of the Wiltshire Association of the Blind, and as moving spirit and Chairman until 1939 of the Foundation Committee of the Bradford-on-Avon District Hospital.

His last public appearance was at the-opening of this Hospital in September, 1947.

His manual dexterity both as an operator and as an amateur carpenter is a lively memory to such few of his colleagues as remain with us.

A more permanent memorial will be his influence on the design of the new Leeds Infirmary buildings, where his architectural ingenuity and untiring work are remembered with gratitude.

His publications include:-

Sarcoma of Iris. Trans. Ophthal. Soc., U.K, Vol. XV, p. 814. 1895.

Cysticercus of conjunctiva. ibid. Vol. XVI, p. 47. 1896.'

Tumour of optic nerve. ibid. p. 139. 1896.

A diagrammatic model intended to assist in the teaching of ocular refraction. ibid. Vol. XXI, p. 142. 1901.

A model to illustrate the passage of rays of light through the eye in the various forms of astigmatism. ibid. Vol. XXV, p. 307. 1905.

Dr Luckhoff of Cape Town, writes :-

"..... How clearly I can visualise him, his springy alertness, his quickness of mind, his cheerful smile, and the quiet efficiency, equanimity, precision, and finish of everything he undertook.

His handwriting to the last showed the neatness, exactness, and good discipline of an orderly mind.

His complete integrity and openness of character was as refreshing as the nature he loved so well. I have no doubt that he was belovéd and admired by all who knew him."

\section{JOHN ROWAN}

JoHN Rowan died at his home near Prestwick on March 17 . A native of Greenock, he retained his love and affection for the West of Scotland throughout his long life. He graduated M.B., C.M., in 
